\title{
The common energy market of the European Union - utopia or reality?
}

\author{
Ana-Maria Iulia ŞANTA \\ The Bucharest University of Economic Studies, Bucharest, Romania \\ anamaria_iulia_santa@yahoo.com
}

\begin{abstract}
The European Commission has the initiative to foster the sector of renewable energy and to build an Energy Union, with a common energy market at the level of the European Union, but is this only an utopic vision or is this possible to achieve? The topic of clean energy is very new and of great interest for the European Union, which is shown by the fact that the European Commission recently adopted on the 30 ${ }^{\text {th }}$ November 2016 the package "Clean Energy for All Europeans", which contains proposals for the modernization of the energy market at the level of the European Union. But which are the challenges such a project is confronted with? According to the literature, such challenges are related to the process of liberalization of electricity markets. Conflicts between national interest and international actors of the energy market might occur. Due to the oligopolistic structure of the energy market, there are several barriers to the market entry. In order to answer to the research questions, case studies regarding the liberalization of the energy market will be analyzed in a comparative manner, offering an international overview. Furthermore, the legal provisions on which the common energy policy of the European Union relies, will be analyzed, as well as their economic and social impact. The package "Clean Energy for All Europeans" comprises a proposal of the revised Renewable energy Directive, energy efficiency measures and issues related to the Energy Union Governance. It contains as well proposals for the electricity market design, which will be analyzed and the present paper outlines the contribution of this proposal in building a common energy market of the European Union. What role does competition play in implementing the common energy market of the European Union? Which role do competition authorities have in this context? These are interesting aspects to be analyzed in the present paper.
\end{abstract}

Keywords: common energy market, energy union, clean energy, renewable energy directive, energy union governance, competition, liberalization.

\section{Introduction}

The field of Clean Energy is one of great interest at the level of the European Union in the context of ensuring consumer welfare and affordable energy prices. This focus on the energy sector can be explained by the concerns regarding the limited resources of the European Union for producing energy.

The European Commission has the initiative to foster the sector of renewable energy and to build an Energy Union (http://ec.europa.eu/priorities/energy-union-andclimate_ro) with a common energy market at the level of the European Union, but is this only an utopic vision or is this possible to achieve? The European Commission published on the 30 $0^{\text {th }}$ November 2016 in the "Clean Energy for All Europeans" package Energy Market Design proposals. It is interesting to analyze which are the challenges in implementing these measures. A new Renewable Energy Directive is part of the package. The Energy Union Governance plays an important role in this context.

In the past twenty years there were several attempts to build a common energy market at the level of the European Union. Some progress has been made, but such a common market of the European Union is still not in place. The present article will analyze 
which steps were taken towards a common energy market of the European Union. It will analyze as well which barriers appeared and why such a common energy market is still a utopia, which are the challenges that the process of creating a common energy market at the level of the European Union encounters. It will analyze as well to what extent this utopia has chances to become reality, taken into account that implementing such a common energy market would bring benefits for the consumers in the European Union. Would it be possible that such a process is blocked due to lack of political support? Is the intention of such a common energy market at the level of the European Union achievable from a political point of view? The fact is that it was difficult to find common point of views of all the Member States of the European Union, as some were willing to liberalize their energy markets and some others were rather reluctant to this liberalization process. Aspects related to competition and to liberalization play an important role in this context.

What brings all the Member States of the European Union together is the fact that all Member States would have benefits from such a project of a common energy market of the European Union, as the European Union could then speak with one voice when negotiating with partners from outside the European Union. This solidarity would ensure a more favorable position in negotiations with energy suppliers from outside the European Union and would make the European Union stronger in these negotiations. According to the official website of the European Commission (http://ec.europa.eu/energy/en/news/commission-proposes-new-rules-consumercentred-clean-energy-transition), the advantages of the measures proposed in the package "Clean Energy for All Europeans" would be a stronger role of the consumer on the energy market, a fair deal for the consumers in the European Union, by offering them convenient energy prices and the possibility of choice, transparency, improved sector regulation, protection of vulnerable consumers, ensuring a sustainable framework by creating jobs and promoting investments and new technologies. According to the European Commission, by adopting the package "Clean Energy for All Europeans" energy efficiency would improve and the economy within the European Union would be modernized, offering better conditions both to consumers and investors, it would promote autonomy in the energy sector and it would reduce energy imports, the European Union would have a transition to clean energy, with less emissions and the energy system would be competitive, modern and clean (http://ec.europa.eu/energy/en/news/commission-proposes-new-rules-consumercentred-clean-energy-transition). Although in theory the project of the common energy market of the European Union seems to bring advantages, the implementation is difficult.

Previous studies and works related to the topic of energy markets have been consulted, for example Fremuth and Parak (2002), Sioshansi and Pfaffenberger (2006), Glachant and Lévêque (2009), Sorrell et al, (2004) and Enchelmaier (1997). The present article is in line with the previous research in these studies and continues it. Research in works and studies analyzing aspects of the energy markets and their evolution have been already conducted, but what the present article brings new is the context of the package "Clean Energy for All Europeans" and the new perspective of a common energy market at the level of the European Union, with the benefits and the challenges related to this European project. As this package has been adopted in November 2016, the topic is very new and there is a research gap in this field. Further research is needed in order to enlighten this topic by analyzing the international context, as the present article does. By 
underlining the changes brought by this international context of the Package "Clean Energy for All Europeans" the present article positions with respect to previous research, being in line with this research and it has a contribution to knowledge and literature, as it contains new elements which are complementary to the evolution of the energy market as presented in the previous studies.

The goal of the present article is to address the following research questions and to offer a perspective on them: Is the project of the European Commission to build a common energy market at the level of the European Union realistic or is this only a utopia? This project is related to economic and social advantages, but is the achievement realistic from a political point of view? Which are the challenges of the common energy market of the European Union? What role does competition play in implementing the common energy market of the European Union? Which role do competition authorities have in this context?

\section{Literature review}

The topic of clean energy is very new and of great interest for the European Union, which is shown by the fact that the European Commission recently adopted on the $30^{\text {th }}$ November 2016 the package "Clean Energy for All Europeans", which contains proposals for the modernization of the energy market at the level of the European Union. Transparency and the focus on the consumer are some key-aspects in this context (https://ec.europa.eu/energy/en/news/new-electricity-market-consumers). But which are the challenges such a project is confronted with? The separate national markets, like in the energy sector, act as obstacles in achieving a single market. By not implementing the common energy market, some goals of the single market of the European Union, like fairness, consumer protection and environmental sustainability may be jeopardized.

According to the literature, such challenges are related to the process of liberalization of electricity markets (Fremuth and Parak, 2002, p. 12). There are several barriers to the market entry due to the oligopolistic structure of the energy market (Enchelmaier, 1997). The studied literature therefore identifies the lack of competition as a main problem why the single energy market is not yet in place. This aspect needs further development and improvement in order to achieve such a common energy market, similar to the internal market of the European Union.

Another problem presented in the literature as an obstacle in creating a common energy market of the European Union is the possible conflict between national interest and the interest of international companies acting in the energy field (Fremuth and Parak, 2002, p. VI). As this field is a strategic one, it is difficult to find the balance between these two types of interest and it is difficult to find the appropriate degree of regulation in this field. It is therefore difficult to find a balance between the degree of regulation needed and the free competition that has to be granted, connected with open access to the market (Sioshansi and Pfaffenberger, 2006).

According to the evaluation of the European Commission (http://ec.europa.eu/energy/sites/ener/files/documents/1_en_autre_document_travail_se rvice_part1_v2.pdf) the implementation of the previous packages for the electricity market within the European Union (The First Package, the Second Package and the Third Package) achieved some progress towards a common energy market, as competition on the electricity markets has been increased, a measure that has positive effects both for the 
market and for the consumer. According to this evaluation, at the level of the retail market the consumer has a better position after introducing the Third Energy Package, as he has the possibility to choose the energy supplier. But there are still obstacles at the level of the wholesale market, represented by the barriers to cross-border trade. Energy poverty remains another challenge to be dealt with. State interventions, which disturb competition, were as well an issue. The package "Clean Energy for All Europeans" can try to solve these remaining aspects by proposing appropriate measures.

\section{Research topics and research methodology}

The concept of Energy Union and of a common energy market at the level of the European Union, with a special emphasis on consumer welfare and on energy efficiency, would for sure bring several advantages from an economic and social point of view, but is this a realistic project from a political point of view? Due to the fact that the energy sector is a strategic sector, some Member States are not willing to give up some competencies to the European Union. A transfer of competencies from the national level to the European Union level would be necessary in order to build an Energy Union, with a harmonized framework, with common regulations and with a common policy.

The package "Clean Energy for All Europeans" comprises a proposal of the revised Renewable energy Directive, energy efficiency measures and issues related to the Energy Union Governance. It contains as well proposals for the electricity market design and the present paper will present the contribution of this proposal in building a common energy market of the European Union.

What role does competition play in implementing the common energy market of the European Union? Which role do competition authorities - the European Commission at the European Union level and national competition authorities at national level - have in this context?

These are interesting aspects to be analyzed in the present paper.

In order to answer to the research questions, case studies regarding the liberalization of the energy market will be analyzed in a comparative manner, offering an international overview. I have chosen the case studies as research method of my paper because I would like to use the concept Lessons learned related to these case studies in order to underline the positive aspects that can be learned from previous experience and to adapt these elements to the present situation of the common energy market of the European Union. Negative aspects from previous experience, which are illustrated in case studies can help in order to avoid these mistakes in the future for the new project of the common energy market. I have chosen the case studies as research method, as they highlight some concrete aspects of the process of liberalization of the market, offering a practical perspective on theoretical issues.

The present paper analyzes case studies from countries and compares them, in order to underline positive experiences from other countries in the field of liberalization of the electricity market and to identify negative aspects that should be avoided in the future. The case studies refer to the electricity liberalization in Britain, to the Nordic Electricity Market and to the German Market. These markets are important and relevant at European level. For comparing reasons, a case study from outside the European Union will as well be 
presented. This refer to the market of the United States of America, including the California Electricity Crisis of 2000 and 2001.

Furthermore, the legal provisions on which the common energy policy of the European Union relies, will be analyzed, as well as their economic and social impact.

Important documents from the package "Clean Energy for All Europeans" related to electricity market design will be analyzed and their impact will be assessed in the present paper.

In the present paper, a multidisciplinary research method will be used, as this will offer more perspectives on the analyzed issues. The common energy market of the European Union will be researched from the perspective of Law and Economics. Law and Economics belong to econosciences (Dinu et al, 2016, p. 34). It is in fact difficult to separate the two fields when analyzing the market and its actors.

Qualitative methods will be used in order to research this topic with a high degree of interdisciplinarity. In many economic papers the qualitative methods are often neglected and the quantitative methods prevail. For the present topic, which is related to strategic questions, it is important to find out how to implement some elements and not what to do. In this case qualitative methods are appropriate, as they search for a response which is a strategic recommendation on how to perform a task, not only what to undertake. This is why I have chosen to use a qualitative method and not a quantitative one, in order to bring a new perspective on the researched issue.

Relevant sector studies, for example from competition authorities (e.g. Competition Council in Romania) will as well be analyzed.

\section{Discussions}

An interesting evolution occurred in the energy field, as this field had to be liberalized and transformed from a sector with high regulation to a sector which permits free competition. In most of the countries of the European Union, the electricity companies had a regional monopoly (Fremuth and Parak, 2002, p. 152). The step of liberalization of the market was connected to the deregulation of the field, which permitted to build new markets. Electricity became a commodity. In this context transparency is a key factor for ensuring the functioning of these markets (Fremuth and Parak, 2002, p. 166). A next step would be to build a common market for the whole European Union, with a common energy policy and with an Energy Union.

The European Union emphasizes the importance of the internal market in general and tries to adapt the model of building an internal market to building a common energy market. But at the moment this energy market is still fragmented. An improved interconnection management and regional cooperation would be needed in order to ensure symmetrical access to information and to auctions in the field of energy in the whole European Union (Glachant and Lévêque, 2009).

As energy is a strategic field, a certain degree of supervision is ensured in all countries by regulation authorities. It is a challenge to find the balance between granting a free market, with free competition and an appropriate level of regulation (Sioshansi and Pfaffenberger, 2006).

The energy market is an oligopolistic market, where market barriers do exist (Enchelmaier, 1997). But the term "barrier" needs to be defined more precisely. Barriers 
are transaction costs, risks or lack of capital, for instance (Sorrell et al, 2004). These barriers act as obstacles in building a common energy market of the European Union. Like for the internal market of the European Union, all barriers should be abolished in order to permit the functioning of the common market.

The first steps in the opening of the electricity market in the European Union were performed in the in the 1990's. The promotor was the European Commission. At the end of 1996 the Directive 96/92/EG has been adopted, which comprised common provisions for the electricity market. The "Second Energy Package" was adopted in 2003 and "The Third Energy Package" was adopted in 2009.

A new step in the development of the energy market is the package "Clean Energy for All Europeans". This measures focus on the renewable energies and on the consumers (https://ec.europa.eu/energy/en/news/new-electricity-market-consumers). A "rulebook" with principles for public authorities and for energy market actors has been proposed. At the level of the retail market, the participation of the consumer is strengthened. The focus on the consumer is a key-point of the European Union Energy strategy. For the wholesale market, the measures foresee a phasing out of discriminatory rules and a more efficient use of the energy network. New rules for risk management are as well foreseen (https://ec.europa.eu/energy/en/news/new-electricity-market-consumers). The proposals for Energy Market Design drafted by the European Commission in the "Clean Energy for all Europeans" package, adopted on the 30th November 2016, were recently discussed at the Energy Market Design conference on the $23^{\text {rd }}$ and the $24^{\text {rd }}$ of January 2017. It is thus a very new topic, of great interest at the level of the European Union.

A legal framework for this common market does therefore exist and was improved in the past 20 years. The question is, if the establishment of such a common market is wanted, what were the main problems why it did not yet succeed to build such a common energy market?

One possible answer could be that the key-word is competition. Being a strategic field, it was difficult to liberalize it. Different Member States had divergent opinions, so that harmonization is not easy in such a situation.

One possible idea is to gradually introduce competition in different segments of the market. Traditional operators have a dominant position at regional level (Fremut and Parak, 2002). Competition aspects do therefore play an important role and these aspects should be kept in mind when drafting the common energy market.

Britain was a good example for the electricity market reform, demonstrating the importance of unbundling and of functional competition. It managed as well to finalize concentration. This is why this model is the most studied model worldwide (Sioshansi and Pfaffenberger, 2006). Britain had a radical liberalization of the electricity market and of reorganization of the sector (Sioshansi and Pfaffenberger, 2006, p. 109). The context in which this occurred is that before liberalization the investment in this field was poor and there was no cost efficiency. This situation may be assimilated to the global situation nowadays at the level of the European Union. The intention was to eliminate a structure with political influenced decisions. In order to achieve this, more competition was introduced on the market by unbundling transmission from generation, by splitting generation into different companies and by creating a wholesale market (Sioshansi and Pfaffenberger, 2006, p. 111). These concrete measures could be taken as well on the level of the European Union in order 
to achieve a functional common energy market. As a measure of market and institutional design, the Electricity Pool was established, where the wholesale spot price of electricity in Britain was determined (Sioshansi and Pfaffenberger, 2006, p. 113). Regarding the competition in generation, the capacity must be divided between many generators, so that no generator has much influence on the price (Sioshansi and Pfaffenberger, 2006, p. 117). These measures could be taken into consideration when designing the common energy market of the European Union.

The example of the Nordic electricity market is interesting, as it shows the resilience to handle stress caused by natural calamities (Sioshansi and Pfaffenberger, 2006, p. 145). The Nordic electricity market comprises Denmark, Finland, Norway and Sweden. The features of the Nordic electricity market are the existing competition in generation and retailing, the regulation of transmission and distribution (Sioshansi and Pfaffenberger, 2006, p. 145), so there is a separation of competitive and monopolistic activities (Sioshans and Pfaffenberger, 2006, p. 145).
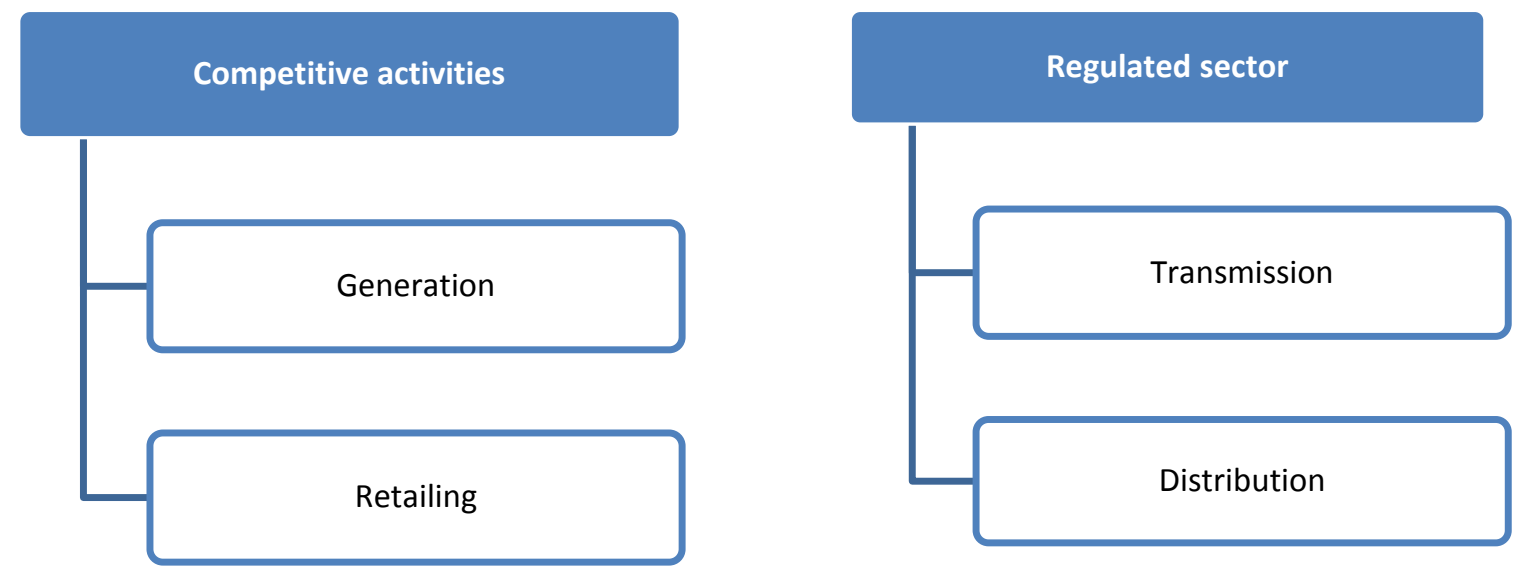

Figure 1. Regulated and not regulated sectors

Source: Own representation based on Fremuth and Parak (2002), p. 164.

There is an establishment of Transmission System Operators (TSOs) which allow consumers the free choice of the supplier (Sioshansi and Pfaffenberger, 2006, pp. 146-148) and there is a zonal pricing system of wholesale energy (Sioshansi, and Pfaffenberger, 2006, p.148). These market features could be applied as well when designing the common energy market of the European Union.

For the German market the focus on environmental issues is typical (Sioshansi and Pfaffenberger, 2006). Investment has an important role on the German energy market, as it affects competition, the environment and the supply adequacy (Sioshansi and Pfaffenberger, 2006, p. 235). At the beginning, Germany did not want to regulate network access, but the system did not function. A regulator has been finally created 
(Bundesnetzagentur, BNA). Network regulation must promote competition and must stimulate new investment by new actors on the market (Sioshansi and Pfaffenberger, 2006, p. 236). It is a difficult task to find the right extent of regulation. Inappropriate regulation, which does not take into consideration the market rules, can result in crisis situations, as it occurred in the United States of America, in the California Electricity Crisis of 2000 and 2001 (Sioshansi and Pfaffenberger, 2006, p. 380).

\section{Results}

The result of the conducted research using the abovementioned case studies is that the common electricity market of the European Union can only function if there is free competition on the market, both at the level of wholesale and of retail market. Open and non-discriminatory access to the market is needed (Glachant and Lévêque, 2009, p. 85). This context would ensure a favorable situation for the consumers within the European Union, which is an important goal when drafting the energy policy of the European Union. General rules from the Competition Theory and provisions regarding EU Competition Law should be observed and applied as well in the field of energy (Littlechild, Stephen, 2016). The competition authorities might have an essential role in this context. The competition authorities which act in the European Union are the European Commission at the level of the European Union and the national competition authorities of the Member States at national level. They cooperate within the European Competition Network. A good approach would be to grant special attention to the consolidation and concentration in the energy field.

The National Competition Authority in Romania (Competition Council) has published a report related to the energy sector. The fact that competition authorities perform such studies shows that this field is now in the focus and that it requires attention.

The low level of interconnection (Mastropietro et al, 2015) is one reason why the energy market is still fragmented in the European Union (Glachant and Lévêque, 2009). Further progress should be achieved in this field, in order to create a functional framework for the common energy market of the European Union.

The institutional framework allowing cooperation is very important. The package "Clean Energy for All Europeans" establishes the Agency for the Cooperation of Energy Regulators (ACER), which aims to foster cooperation in the energy sector at the level of the European

Union (http://ec.europa.eu/energy/sites/ener/files/documents/1_en_autre_document_travail_s service_part1_v2.pdf).

\section{Conclusion}

Due to the fact that the topic of clean energy and of a common energy market of the European Union is very new, in this field there is a research gap which I have identified. The present paper brings a contribution to the analysis of the recent projects of the European Commission regarding the common energy market of the European Union, the proposals for the electricity market design, the project of an Energy Union with main focus on the consumer and on its benefits. This field is dynamic and it will further improve in future, so that such studies will be necessary. 
The topic is of great importance. The fact that over the past twenty years several attempts have been made in order to harmonize the provisions of the energy sector and to build a common framework shows that a common market in this field is needed. The challenges encountered in establishing this market are caused by the fact that being a strategic sector, it is difficult to find the right balance between regulation and ensuring free competition of the sector.

PICBE | 101

The problem identified why there is no common energy market yet, although this is desired, is that there still is lack of competition in this field, which leads to a fragmentation of the market. Having an oligopolistic market structure, dominant positions of traditional suppliers are possible and they are connected to possible abuse of dominance of these companies. The competition authorities - the European Commission at the European Union level and national competition authorities at national level - might play an important role in this context. More workable competition would improve the situation, as it did in the case of the internal market of the European Union. The conclusion that competition is needed is resulting as well from the case studies that were analyzed in this paper.

A better interconnection and cooperation between the institutions and actors in the field would as well contribute to creating a common energy market by ensuring an appropriate common framework, supported by the institutional level. This would allow a better cooperation in the energy sector, it would help to avoid the fragmentation of the market and it would contribute to building a common energy market of the European Union.

These results of the paper might be used as well in future research, as the field is now developing and further research will for sure be needed.

\section{Bibliography/References}

Biskup, R. (1996). Globalisierung und Wettbewerb. Bern, Stuttgart, Wien: Verlag Paul Haupt, 290-300.

Dinu, V., Săvoiu, G., Dabija, D.-C. (2016). A concepe, a redacta și a publica un articol știinţific: o abordare în contextul cercetării economice. București: Editura ASE.

Enchelmaier, S. (1997). Europäische Wettbewerbspolitik im Oligopol: eine Untersuchung der Behandlung von Oligopolfällen durch die Kommission und den Gerichtshof der Europäischen Gemeinschaften. Baden-Baden: Nomos-Verl.-Ges., 35-42.

Fremuth, W., Parak, C. (2002). Regulierung der Deregulierung von Infrastrukturmärkten. Wien: Manzsche Verlags- und Universitätsbuchhandlung.

Glachant, J.-M., Lévêque, F. (2009). Electricity reform in Europe - Towards a Single Energy Market. Cheltenham, UK, Northhampton, MA, USA: Edward Elgar Publishing Limited.

Littlechild, S. (2016). The CMA energy market investigation, the well-functioning market, Ofgem, Government and behavioural economics. European competition journal [1744-1056], pp. 1 -63.

Mastropietro, P., Rodilla, P., Batlle, C. (2015). National capacity mechanisms in the European internal energy market: Opening the doors to neighbours. Energy policy, 82, 38 -47.

Sorrell, S., O’Maley, E., Schleich, J., Scott, S. (2004). The Economics of Energy Efficiency. Cheltenham, UK, Northhampton, MA, USA: Edward Elgar Publishing Limited. 
Sioshansi, F., P., Pfaffenberger, W. (2006). Electricity market reform - an international perspective. Oxford: Elsevier.

Official website of the European Commission retrieved from URL https://ec.europa.eu/energy/en/news/new-electricity-market-consumers [accessed on 09.02.2017].

Official website of the European Commission retrieved from URL PICBE|102 http://ec.europa.eu/priorities/energy-union-and-climate_ro [accessed on 09.02.2017].

Official website of the European Commission retrieved from URL https://ec.europa.eu/energy/en/consultations/public-consultation-new-energymarket-design [accessed on 09.02.2017].

Official website of the European Commission retrieved from URL http://ec.europa.eu/energy/sites/ener/files/documents/1_en_autre_document_trav ail_service_part1_v2.pdf [accessed on 09.02.2017]..

Official website of the European Commission retrieved from URL http://ec.europa.eu/energy/en/news/vice-president-

\%C5\%A1ef\%C4\%8Dovi\%C4\%8D-and-commissioner-arias-ca\%C3\%B1ete-duespeak-energy-market-design-conference [accessed on 09.02.2017].

Official website of the European Commission retrieved from URL http://ec.europa.eu/energy/en/news/commission-proposes-new-rules-consumercentred-clean-energy-transition [accessed on 04.03.2017]. 